\title{
Hospital Waste Management in Hospitals of Karachi, Sindh, Pakistan
}

\author{
Angel Aslam Imdad ${ }^{1}$, Ahmad Hussain ${ }^{2}$, Abdul Hameed Memon ${ }^{3}$, Rija Nadeem Nizami ${ }^{4}$,Waqar Hussain \\ Phulpoto ${ }^{5}$. \\ 1.Department of Engineering Sciences \& Technology (FEST), Hamdard University, Karachi, Pakistan. \\ 2.Department of Mechatronics Engineering, Shaheed Zulfikar Ali Bhutto Institute of Science and Technology \\ (SZABIST), Karachi, Pakistan.
}

3. Department of Engineering Sciences \& Technology (FEST), Hamdard University, Karachi, Pakistan.

4. Department of Environmental Sciences, Jinnah University for Women, Karachi, Pakistan. 5.Department Sindh Environmental Protection Agency, Karachi, Pakistan.

\section{ABSTRACT}

Hospital Waste (HW) constitutes a special category of waste because they contain potentially infectious materials. The problem of how to manage HW has become one of critical concerns in developing countries. The present study was conducted to evaluate the awareness regarding different constituents of wastes, their handling, treatment and disposal methods in different hospitals of Karachi, Sindh, Pakistan. Four (4) hospitals, 2 Government and 2 Private Hospitals were surveyed using a modified survey questionnaire for hospital waste management. This questionnaire was designed in the light of regulation of Sindh Hospital Waste Management Rules 2014, established by Government of Sindh, with the aim of implementing these rules in healthcare processing systems for HW handling, treatment and disposal. As result, hazards associated with poor HW management and shortcomings in the existing system were identified.

Keywords - Hospital waste disposal, Waste management, Biohazardous Waste, Infectious waste, Segregation, Incineration, Sindh Hospital Waste Management Rules 2014,

DOI: $10.7176 / \mathrm{JNSR} / 9-12-06$

Publication date:June $30^{\text {th }} 2019$

\section{INTRODUCTION}

In today's world, with the rise of industrial, economic, agricultural development, there is outrage advancement in medical sciences since $20^{\text {th }}$ century. This advancement in medical sciences has led to raise life expectancy by giving the right medical services to the young and old, thus expanding the number of patients in a healthcare center. Higher the number of medical services, higher the number of patients, which leads to higher biohazardous waste from healthcare vicinity. The waste that is being generated from any medical facility such as Hospitals, Clinics etc is known as biohazardous waste or hospital waste. This hospital waste generated during the health care process of patients comprises of all types of waste, though only $20 \%$ of which is toxic and requires specialized waste disposal techniques. This waste includes syringes, needles, scalpers, gloves, clothes, expired or discarded medicines, body tissues and organs, body fluids, chemicals etc. Radioactive materials, instruments that contain mercury are the highest environmentally susceptible healthcare by-products and needs a greater attention, which has to be monitored (Carnero 2015). Although, this cycle of resource consumption, which eventually produces chemical, as well as biohazardous waste influences climate change are associated with the growth of diseases around the world. (Azmal et al. 2014)

Considering the present picture of city Karachi in terms of waste management, particularly the hospital waste possess high risk to public residing around the healthcare facilities, workers handling the waste and to the patients admitted for treatment. Additionally, huge quantities of water, energy, and non-biodegradable carcinogenic plastics are being utilized during the delivery of healthcare services by hospital staff (Pinzone et al. 2015). It was observed that hospital waste handlers are on the highest risk of getting infectious diseases due to poor precautionary measures taken specially, use of personal protective equipment (PPE) during waste collection, segregation, and disposal of hospital waste (Assis et al. 2017; A. Kumar et al. 2015). Considering these health and environmental effects, uncertainty regarding regulations and negative perceptions by waste handlers are some important concerns in hospital waste management in a developing country (Huffling et al. 2014). Although, maintaining health of the patients and the communities is the core purpose of these healthcare facilities. (Russo 2016)

HWM plays an important role in reducing pollution that leads to environmental degradation and climate variation (Patrick et al. 2016) which builds healthier, safer, and greener workplaces and societies. (Caniato et al. 2015; 
Practice Greenhealth 2016). The proposed Sindh Hospital Waste Management Rules 2014, is a document liable with the hospital waste (management and handling) Rules, Ministry of Sindh, Pakistan. The implication of these rules will increase the wellbeing of the hospitals' neighboring societies as well. (Andrea Clark 2018) Furthermore, this survey aims to evaluate the hospital's waste handling and management in number of different hospitals situated in different districts of Karachi, Sindh, Pakistan.

\section{METHODOLOGY}

A self-reported questionnaire for hospital waste management was designed in the light of Sindh Hospital Waste Management Rules 2014. The questionnaire survey was conducted with managers and supervisors of the four (4) hospitals.

\section{RESEARCH ANALYSIS}

Some of the managers have their concern about the high-cost waste management strategies (Arend, 2014) which restricts them to adopt any sustainable practices (Coffey et al. 2013; Dhillon et al. 2015), although missegregation of the healthcare waste is one of the major factors that increases the cost of its treatment (Johnson et al. 2013). However, the Government of Sindh has formulated Sindh Hospital Waste Management Rules 2014, in order to identify procedures that needs to be followed in the management and disposal of hospital waste (HW). These rules regulate disposal of HW including human anatomical waste, blood, body fluids, medicines, glassware, soiled, liquid \& biotechnology waste and animal waste. The rules have been formulated as a guideline for handling \& management of HW, which will help to reduce landfills waste quantities' and threat of spreading contagious diseases will be decreased (Andrea Clark 2018). These rules are applicable to all hospitals, nursing homes, clinics in the province of Sindh and apply to all individuals who generate, collect, receive, store, transport, treat, dispose or handle HW in any form.

\section{A. STUDY SAMPLES}

A study was conducted in contrast to 2 different Government and 2 different Private Hospital settings. Data was collected from various districts in Karachi, Pakistan i.e. District Central, District South and District Korangi from October 2017 to May 2018. Using purposive sampling technique, managers and supervisors were selected for the interview based on the survey questionnaire (Lee-Jen Wu et al. 2014; Hovlid et al. 2012). The hospitals, which are surveyed during the study, are believed to be large scale hospitals on the basis of their bed space capacity, as each consist of 100 bed space capacity.

\section{B. TYPE OF WASTE}

Segregation is the backbone of waste management (Manzi 2014). The basic division of HW can be a. Risk Waste (Infectious Waste) which includes Sharps, Pathological waste, Pharmaceutical waste, chemical waste, radioactive waste. b. Non-Risk Waste (Non-Infectious Waste) includes Food waste, Paper, Glass. Different containers needs to be used in each ward and department in order to segregate risk waste from non-risk waste at the waste generation source, this leads to safe disposal of waste and reduces the chances of infection to the person handling the waste.

\section{QUANTITY OF WASTE}

The quantity of waste generated in hospitals should be known in order to maintain a good waste management system. Hence, the quantities of different categories of hospital waste have to be estimated by checklists, record maintenance, discussions and physical checks. The quantities generated vary from hospital to hospital and depend on the type of health-care facility and local economic conditions. Hospital wastes can be categorized into two types, which are infectious waste and non-infectious waste. A large fraction of non-infectious waste is potentially recyclable but may be contaminated with infectious agents. This has to be separately stored and sterilized before sending for recycling (Doiphode et al. 2016).

\section{DATA ANALYSIS}

The data was gathered during the survey of four (4) different hospitals, two (2) government and two (2) private. The data was evaluated and compiled in Table $\mathbf{I}$. 


\section{RESULTS}

The data of comprehensive survey of Hospital waste management rules conducted in two Government and two Private hospitals are given in Table I. According to Sindh Hospital Waste Management Rules 2014, the shortcomings observed in the systems are:

1. Risk waste is not being separated from non-risk waste at the point where the waste is being generated in almost all the hospitals.

2. A separate, isolated with maintained hygiene central waste storage facility not established.

3. In one of the biggest city, where treatment facilities are common but most of the hospitals do not have proper treatment and disposal facilities yet.

4. Hospital waste which is being disposed-off, its quantity and frequency records are poorly maintained.

5. Mechanism of disposal of Hospital waste including used syringes, needles, drips is extremely poor which leads to the recycling of these syringes and drips for the manufacturing of disposal plastic utensils which is a huge threat to human health. Whereas, needles are being used by the local drug addicts and causing HIV.

6. Regular immunization is not being offered to the workers who deal with the waste handling at any hospital.

7. No teams are formed to delegate the duties in hospitals regarding the waste and to introduce new strategies to handle Hospital waste in a better manner.

8. Lack of awareness and knowledge among the staff regarding Hospital Waste management.

9. Trainings are not being conducted in the Hospitals to spread awareness of Hospital Waste Management Rules 2014 which refers that how they can control the spreading of infectious disease and save public health.

10. No hospital holds a license for handling hazardous substances according to section 13 and 14 of Sindh Environmental

\section{CONCLUSION}

The results clearly show that the hospitals in Karachi, Sindh, Pakistan severely lack in hospital waste management. Research state that healthcare top management's commitment towards maintaining sustainable environment encourages the workers to adopt green practices (Sari and Camponogara 2014). The sole issue is lack of awareness, education and realization among the administration and workers of the hospitals about the importance of managing this waste in order to reduce the solid waste quantity as well as to protect the public health. To maintain waste management in hospitals, segregation through color coding system is the key element through which handling and disposal will consume half of the time and cost. The mixing of waste allows the waste pickers and workers to collect the syringes and drips and sell them to disposable plastic utensils manufacturers, which is causing various diseases to the public. This arise the need of strict enforcement of legal provision and to develop a Hospital Waste Management Plan in accordance with Sindh Hospital Waste Management Rules 2014 and attain a license for handling this waste. Implementing these rules will support healthy environment and communities (Thakur \& Ramesh, 2015). The survey study comprises that hospital waste management can be more supported by education, training and commitment of the hospital staff and management according to the legislations and Rules defined in policy framework (Amal Sarsour, et al. 2014).

\section{REFERENCES}

1. Amal Sarsour, et al, (2014). Assessment of Medical Waste Management within Selected Hospitals in Gaza Strip Palestine; International Journal of Scientific Research in Environmental Sciences, 2 (5), pp. 164-173. doi: 10.12983/ijsres-2014-p0164-0173

2. Andrea Clark. (2018). Waste Management Minimization Strategies in Hospitals. Walden University. Retrieved from $\underline{\text { https://scholarworks.waldenu.edu/cgi/viewcontent.cgi?article }=6343 \& \text { context }=\text { dissertations }}$ 
3. Arend, R. J. (2014). Social and environmental performance at SMEs: Considering motivations, capabilities, and instrumentalism. Journal of Business Ethics, 125, 541-561. doi:10.1007/s10551-0131934-5

4. Assis, M. C., Gomes, V. P., Balista, W. C., \& Freitas, R. D. (2017). Use of performance indicators to assess the solid waste management of health services. Anais Da Academia Brasileira De Ciencias, 89, 2445-2460. doi:10.1590/00013765201720170178

5. Azmal, M., Kalhor, R., Dehcheshmeh, N. F., Goharinezhad, S., Heidari, Z. A. and Farzianpour, F. (2014). Going toward green hospital by sustainable healthcare waste management: Segregation, treatment and safe disposal. Health, 6, 26322640. doi:10.4236/health.2014.619302

6. Caniato, M., Tudor, T., \& Vaccari, M. (2015). International governance structures for health-care waste management: A systematic review of scientific literature. Journal of Environmental Management, 153, 93-107. doi:10.1016/j.jenvman.2015.01.039

7. Carnero, M. C. (2015). Assessment of environmental sustainability in health care organizations. Sustainability, 7, 8270-8291. doi:10.3390/wsf-4-c001.

8. Coffey, P., Tate, M., \& Toland, J. (2013). Small business in a small country: Attitudes to "Green" IT. Information Systems Frontiers, 15, 761-778. doi:10.1007/s10796013-9410-4

9. Dhillon, V. S., \& Kaur, D. (2015). Green hospital and climate change: Their interrelationship and the way forward. Journal of Clinical and Diagnostic Research [Online], 9(12), LE01-LE5. doi:10.7860/JCDR/2015/13693.6942.

10. Doiphode, S. M., Hinduja, I. N., \& Ahuja, H. S. (2016). Developing a novel, sustainable and beneficial system for the systematic management of hospital wastes. Journal of Clinical \& Diagnostic Research [Online], 10(9), LC06-LC11. doi:10.7860/JCDR/2016/21384.8521

11. Hovlid, E., Bukve, O., Haug, K., Aslaksen, A. B., \& von Plessen, C. (2012). Sustainability of healthcare improvement: What can we learn from learning theory? BMC Health Services Research [Online], 12(1), 235-247. doi:10.1186/1472-6963-12-235

12. Huffling, K., \& Schenk, E. (2014). Environmental sustainability in the intensive care unit. Critical Care Nursing Quarterly, 37, 235-250.doi:10.1097/CNQ.0000000000000028

13. Johnson, K. M, González, M. L., Dueñas, L., Gamero, M., Relyea, G., Luque, L. E., \& Caniza, M. A. (2013). Improving waste segregation while reducing costs in a tertiary-care hospital in a lower-middleincome country in Central America. Waste Management and Research, 31, 733-738. doi:10.1177/0734242X13484192

14. Kumar, A., Duggal, S., Gur, R., Rongpharpi, S. R., Sagar, S., Rani, M., ... \& Khanijo, C. M. (2015a). Safe transportation of biomedical waste in a health care institution. Indian Journal of Medical Microbiology, 33, 383-386. doi: 10.4103/02550857.158559

15. Lee-Jen Wu, S., Hui-Man, H., \& Hao-Hsien, L. (2014). A comparison of convenience sampling and purposive sampling. Journal of Nursing, 61(3), 105-111. doi:10.6224/JN.61.3.105

16. Manzi, S., Nichols, A., \& Richardson, J. (2014). A non-participant observational study of health and social care waste disposal behaviour in the South West of England. Journal of Health Services Research \& Policy, 19, 231-235. doi:10.1177/1355819614538780

17. Patrick, R., Kingsley, J., \& Capetola, T. (2016). Health-related education for sustainability: Public health workforce needs and the role of higher education. Australian Journal of Environmental Education, 32, 192-205. doi:10.1017/aee.2016.11

18. Pinzone, M., Lettieri, E., \& Masella, C. (2015). Proactive environmental strategies in healthcare organisations: Drivers and barriers in Italy. Journal of Business Ethics, 131, 183-197. doi:10.1007/s10551-014-2275-8

19. Practice Greenhealth. (2016). Material and waste streams. Retrieved from https://practicegreenhealth.org

20. Russo, F. (2016). What is the CSR's focus in healthcare? Journal of Business Ethics, 134, 323-334. doi:10.1007/s10551-014-2430-2

21. Sari, V., \& Camponogara, S. (2014). Challenges of environmental education in a hospital institution. Texto \& Contexto-Enfermagem, 23, 469-478. doi:10.1590/01040072014001130013

22. Thakur, V., \& Ramesh, A. (2015). Healthcare waste management research: A structured analysis and review (2005-2014). Waste Management \& Research, 33, 855-870. doi:10.1177/0734242X15594248 
Table I: Data Evaluation of Hospital Waste Management Practice at Hospital in Karachi.

\begin{tabular}{|c|c|c|c|c|c|}
\hline & $\begin{array}{l}\text { HOSPITAL WASTE } \\
\text { MANAGEMENT } \\
\text { PRACTICE AT } \\
\text { HOSPITALS }\end{array}$ & $\begin{array}{l}\text { GOVT } \\
\text { HOSPITAL } \\
\text { I }\end{array}$ & $\begin{array}{l}\text { GOVT } \\
\text { HOSPITAL } \\
\text { II }\end{array}$ & $\begin{array}{l}\text { PRIVATE } \\
\text { HOSPITAL I }\end{array}$ & $\begin{array}{l}\text { PRIVATE } \\
\text { HOSPITAL } \\
\text { II }\end{array}$ \\
\hline 01 & $\begin{array}{l}\text { Sindh Hospital waste } \\
\text { management rules } \\
\text { awareness? }\end{array}$ & $\mathrm{NO}$ & YES & YES & YES \\
\hline 02 & $\begin{array}{l}\text { License for handling } \\
\text { Hospital waste? }\end{array}$ & $\mathrm{NO}$ & $\mathrm{NO}$ & $\mathrm{NO}$ & $\mathrm{NO}$ \\
\hline 03 & $\begin{array}{l}\text { Hospital waste } \\
\text { management plan } \\
\text { prepared? }\end{array}$ & $\mathrm{NO}$ & $\mathrm{NO}$ & YES & $\mathrm{NO}$ \\
\hline 04 & $\begin{array}{l}\text { Hospital waste } \\
\text { management team to } \\
\text { review and monitor? }\end{array}$ & NO & YES & $\mathrm{NO}$ & $\mathrm{NO}$ \\
\hline 05 & $\begin{array}{l}\text { Hospital waste being } \\
\text { segregated at source of } \\
\text { generation? }\end{array}$ & $\mathrm{NO}$ & YES & $\mathrm{NO}$ & $\mathrm{NO}$ \\
\hline 06 & $\begin{array}{l}\text { Color coding system for } \\
\text { various waste categories? }\end{array}$ & $\mathrm{NO}$ & YES & YES & $\mathrm{NO}$ \\
\hline 07 & $\begin{array}{l}\text { Quantification of risk and } \\
\text { non-risk waste? }\end{array}$ & $\mathrm{NO}$ & $\mathrm{NO}$ & $\mathrm{NO}$ & $\mathrm{NO}$ \\
\hline 08 & $\begin{array}{l}\text { Is storage area of waste } \\
\text { isolated? }\end{array}$ & NO & YES & YES & $\mathrm{NO}$ \\
\hline
\end{tabular}




\begin{tabular}{|l|l|l|l|l|l|}
\hline 09 & $\begin{array}{l}\text { Hygiene maintained in } \\
\text { storage area? }\end{array}$ & NO & YES & NO & NO \\
\hline 10 & $\begin{array}{l}\text { Incinerator/Sterilizer } \\
\text { facility available? }\end{array}$ & NO & $\begin{array}{l}\text { YES } \\
\text { (Sterilizer) }\end{array}$ & NO & NO \\
\hline 11 & $\begin{array}{l}\text { Is the Hospital waste being } \\
\text { transferred to other place } \\
\text { for treatment? }\end{array}$ & YES & NO & YES & YES \\
\hline 12 & $\begin{array}{l}\text { Are personal protective } \\
\text { equipment (PPE) being } \\
\text { used by workers? }\end{array}$ & NO & YES & YES & NO \\
\hline 13 & $\begin{array}{l}\text { Immunization of sanitary } \\
\text { staff? }\end{array}$ & NO & NO & NO & NO \\
\hline 14 & $\begin{array}{l}\text { Waste handling trainings } \\
\text { being conducted? }\end{array}$ & NO & NO & NO & NO \\
\hline
\end{tabular}




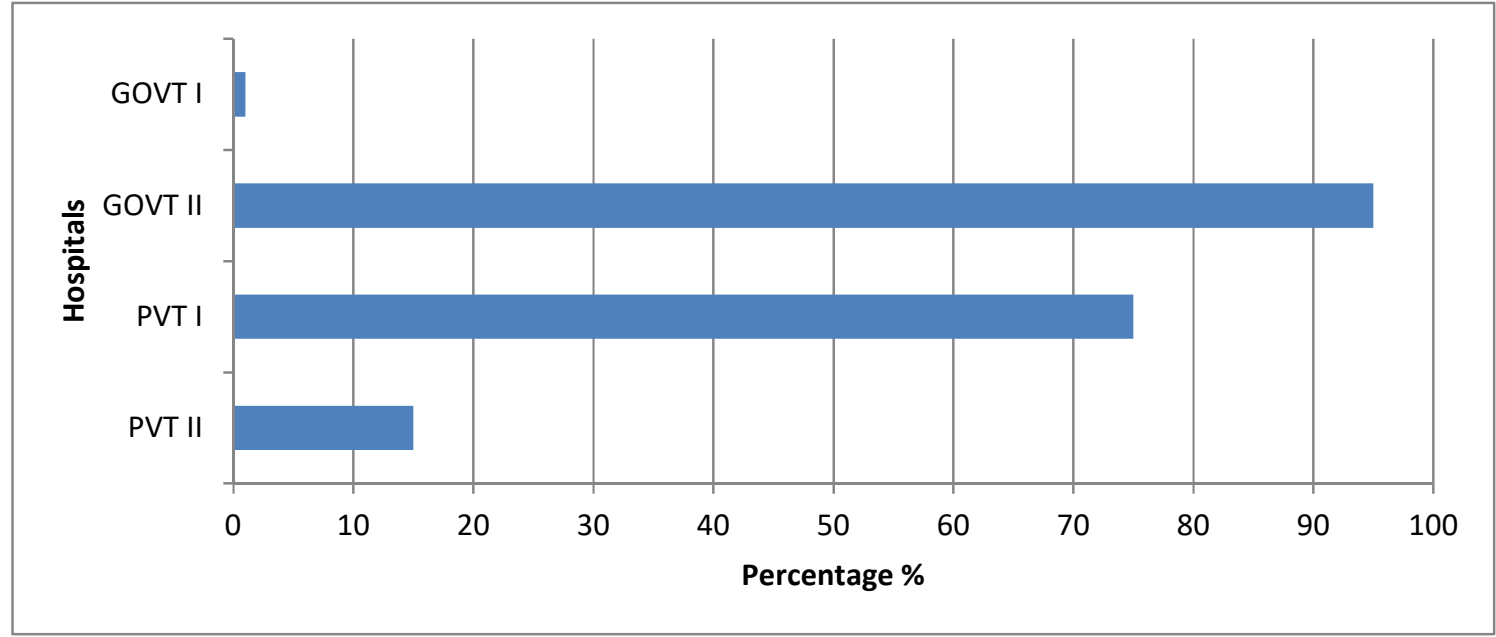

Graph I. Awareness of Hospital Waste Management.

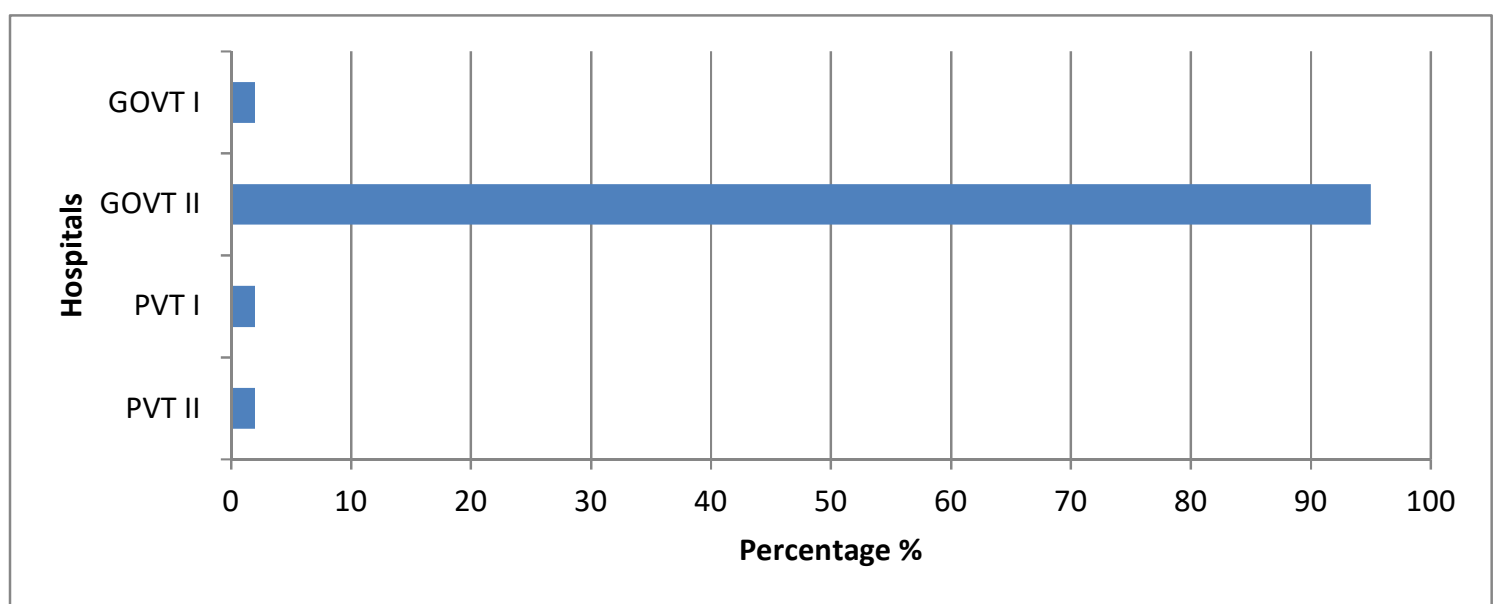

Graph II. Hospital Waste Management Monitoring Team

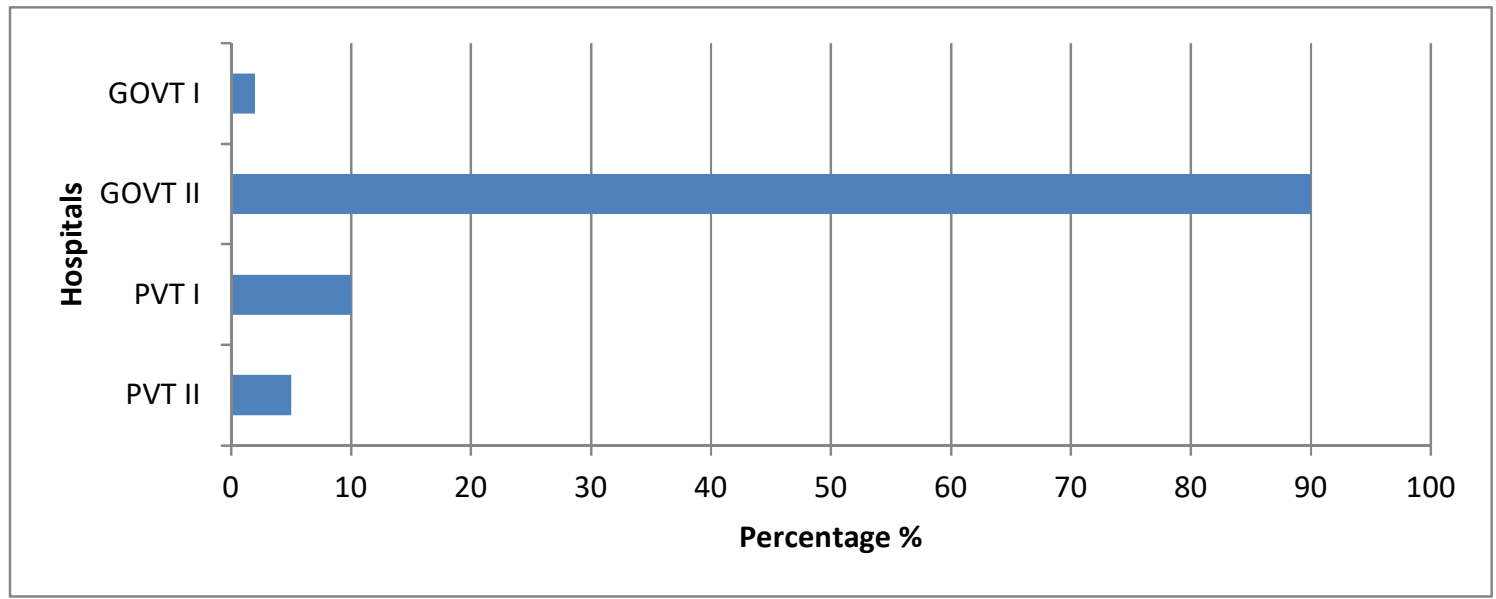

Graph III. Hospital Waste Segregation. 


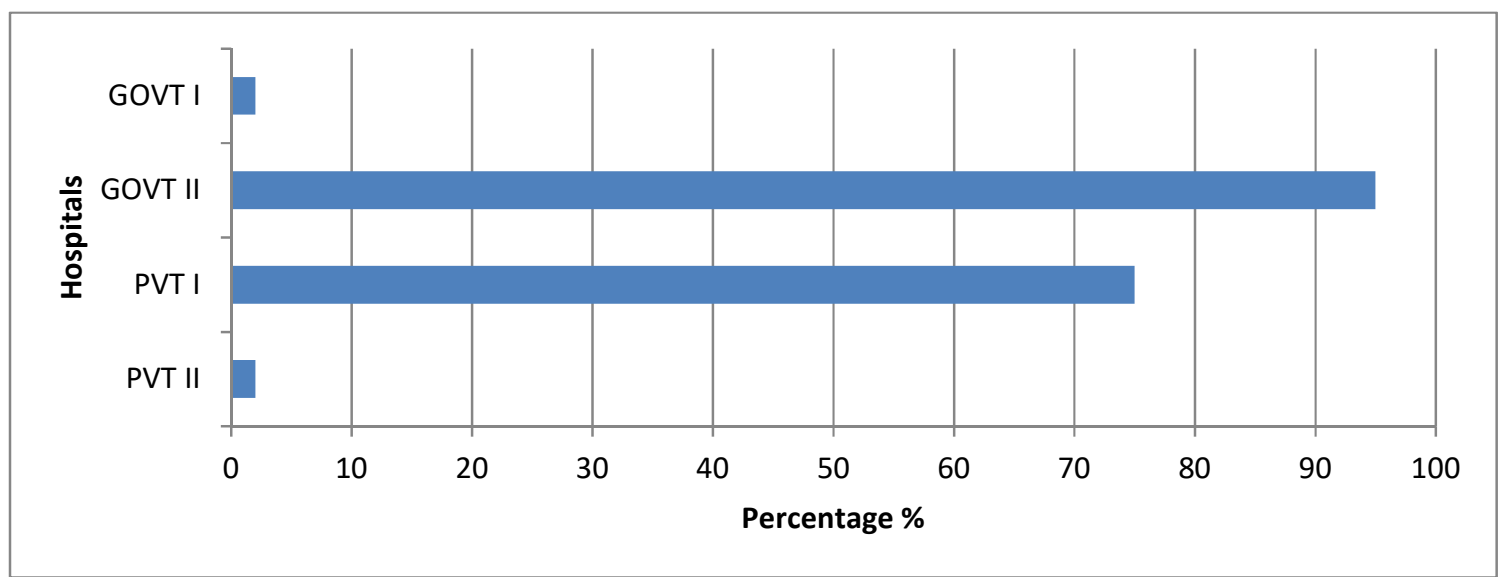

Graph IV. Color Coding System.

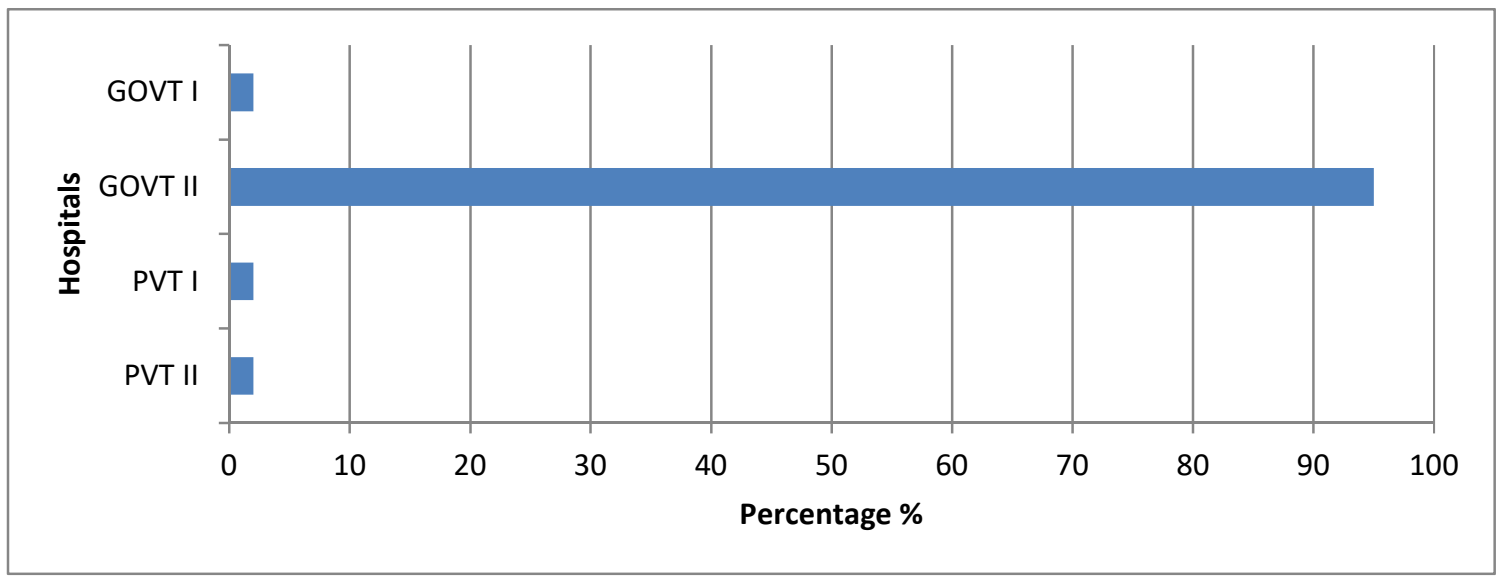

Graph IV. Incinerator/Sterilizer.

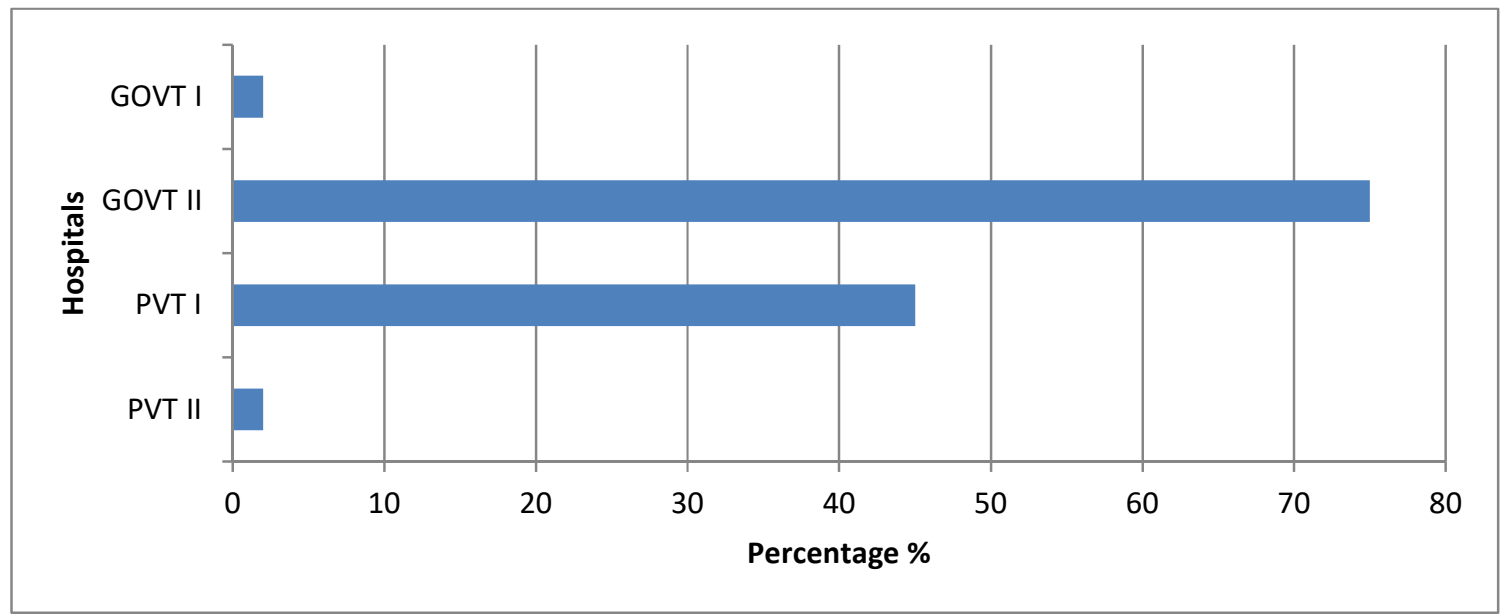

Graph V. Personal Protective Equipment. 


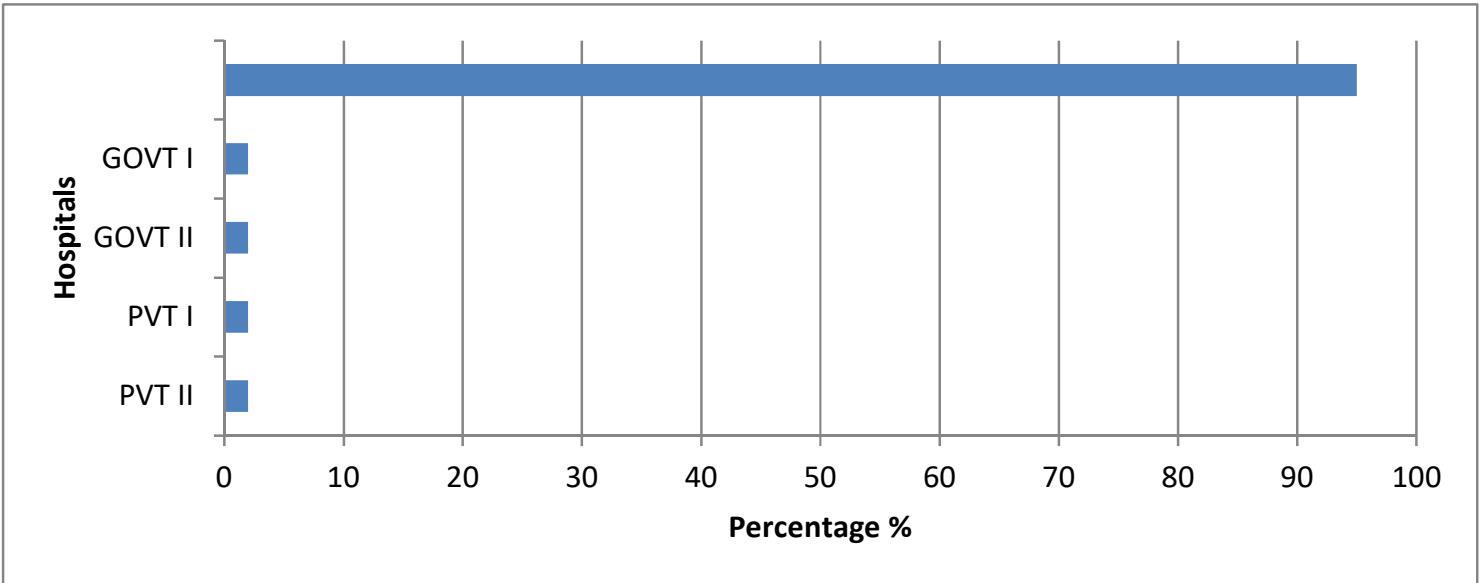

Graph VII. Immunization \& Training of Workers. 